\title{
Economic globalization in the global post-crisis of 2008: limits and deadlocks
}

\author{
Globalização econômica no pós-crise \\ global de 2008: limites e impasses
}

RAFAEL HENRIQUE DIAS MANZI*

RESUMO: A globalização econômica entrou em uma nova fase de relativa estagnação e arrefecimento a partir do início da crise global de 2008. O principal objetivo desse artigo é examinar as dinâmicas que explicam o arrefecimento do processo de globalização econômica a partir do início da crise global de 2008. Os resultados iniciais indicam que o processo de estagnação das forças globais não está ligado apenas a uma conjuntura de menor crescimento econômico da própria economia global após 2008, mas também reflete principalmente dinâmicas políticas no âmbito dos estados nacionais e do próprio sistema internacional que possuem impacto direto sobre o fenômeno da globalização econômica. PALAVRAS-CHAVE: Globalização econômica; crise global de 2008; governança global; populismo; economia internacional.

ABSTRACT: Economic globalization has entered a new phase of relative stagnation and cooling since the beginning of the global crisis of 2008. The main objective of this article is to examine the dynamics that explain the stagnation of the economic globalization process from the beginning of the global crisis of 2008. The initial results indicate that the process of stagnation of global forces is not only related to a scenario of lower economic growth of the global economy after 2008 , but also reflects mainly political dynamics within national states and the international system itself that have a direct impact on the phenomenon of economic globalization.

KEYWORDS: Economic globalization; global crisis of 2008; global governance; populism; international economy.

JEL Classification: F02; F06; F68.

\footnotetext{
* Universidade de Brasília - UnB, Brasília/DF, Brasil. E-mail: rafaelmanzi@hotmail.com. ORCID: https:// orcid.org/0000-0001-8518-8329. Submitted: 5/March/2018; Approved: 19/December/2018.
} 


\section{INTRODUCTION}

The article's main objective is to examine the dynamics that involve the process of economic globalization from the beginning of the global crisis of 2008, and to answer some questions: Does the reduction of the speed of the process of internationalization of national economies point to a stagnation or even reversion of economic globalization from 2008? Does this phenomenon exclusively reflect the economic dynamics due to the global crisis of 2008? Which factors explain this process of cooling down of the global economy from 2008?

The central argument of this article is that the cooling down, or outright stagnation, of the process of economic globalization is reflective of structural dynamics and not only the post-2008 global economic conjuncture. Even considering the effects of the global crisis of 2008 on the dynamics of economic globalization, it nonetheless becomes possible to identify elements of a mainly political nature that explain the lacking momentum of the forces of globalization, mainly from the biennium 2016/2017. This scenario does not evidence a process of reversion of globalization, as occurred in the decade of the thirties when the global order of the $19^{\text {th }}$ century deteriorated due to the ascent of autarchic nationalism, represented by fascist and authoritarian regimes within the international system. Rather, this relative deceleration of the international economic flows pave the way for a new phase in the process of economic globalization, marked by a slow expansion of the international economic interactions, mainly rooted in the existence of an impasse within national politics, in the international system, and a decline of the very ideological underpinnings which had propelled the process of economic globalization.

The article is divided into two sections. The first is of a more descriptive character, and will present the evolution of the main indicators that affect the phenomenon of economic globalization. The second part is predominantly analytical, and will conduct an analysis and discussion with regards to the variables that explain the cooling down of the process of economic globalization from the eruption of the global crisis in 2008.

\section{ECONOMIC GLOBALIZATION: FROM ACCELERATION (1990-2008) TO A PERIOD OF DECELERATION AND STAGNATION (2008-2017)}

Globalization can be understood as a material and ideational phenomenon or process which reduces the spatial distance between distinct geographical regions. It is, above all, a phenomenon of historical and multidimensional evolution. Therefore, it becomes necessary to analyze globalization as a process of advances and retrocession, and not merely as a process of constant historical evolution.

According to Held and McGrew (2001, p.12-13) globalization "suggests an increasing magnitude or intensity of global flows, such that states and societies are increasingly entangled in global systems and networks of interaction". As a result of this process, the authors accentuate that "distant occurrence and phenomena can have serious internal impacts while local events can generate global repercussions”. 
The international system underwent two phases of acceleration of the process of economic globalization from the eruption of the industrial revolution in the end of the 18th century. The first was marked by a period of acceleration, mainly from the last quarter of the 19th century, which continued until the beginning of the First World War. In this period, a significant expansion of international trade and long-term foreign investment can be observed. (Frieden, 2006).

A second phase of intense acceleration of economic globalization had its beginning in the 1990s. This period is marked by a significant growth of international economic relations with regards to international trade, multinational enterprises and long-term international investments, and is also rooted in a growing internationalization of international finance.

Held et al (1999) highlight how economic globalization can be treated as three pillars: commercial, productive, and financial globalization. This does not necessarily imply that these pillars are completely distinct, but rather that the process of economic globalization also can be viewed through specific dimensions. Commercial globalization can be observed mainly through the flows of international trade within the international system. The main actors within this process are private and public enterprises, and national governments that engage in international trade. Financial globalization is characterized by transactions that involve the purchase and sale of currency, derivate and future markets operations, short-term portfolio investments, international bank loans, and long-term investments (FDI) that involve international investors. Finally, productive globalization is a phenomenon which mainly is linked to the process of expansion of multinational enterprises and the growth of international long-term investments.

Graph 1: World trade (\% of Global GDP)

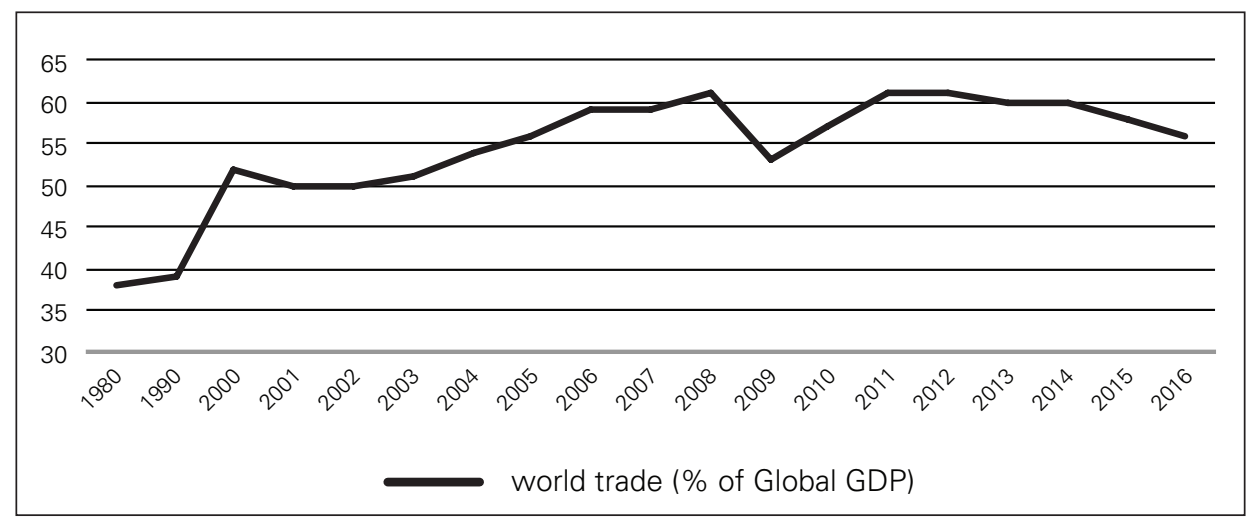

Source: Graph elaborated by the author according to data from the World Bank.

Available at: http://data.worldbank.org/indicator/NE.TRD.GNFS.ZS Access: January 18, 2018.

The acceleration of global trade is displayed in Graph 1, which shows the percentage of international trade in relation to the global GDP. The percentage of international trade in relation to world GDP increased from $39.2 \%$ in 1990 , to 
$51.5 \%$ in 2000 , and peaked in 2008 when it reached $61 \%$ of global GDP. This process of expansion was interrupted at the beginning of the global crisis of 2008, when international trade underwent a strong reduction mainly in 2009. Even after the recovery of the global trade from 2010, the levels of expansion of the trade flows stagnated in relation to the level of global wealth.

Graph 2: Global FDI stock (\% of global GDP)

and $\%$ of FDI stocks in group countries

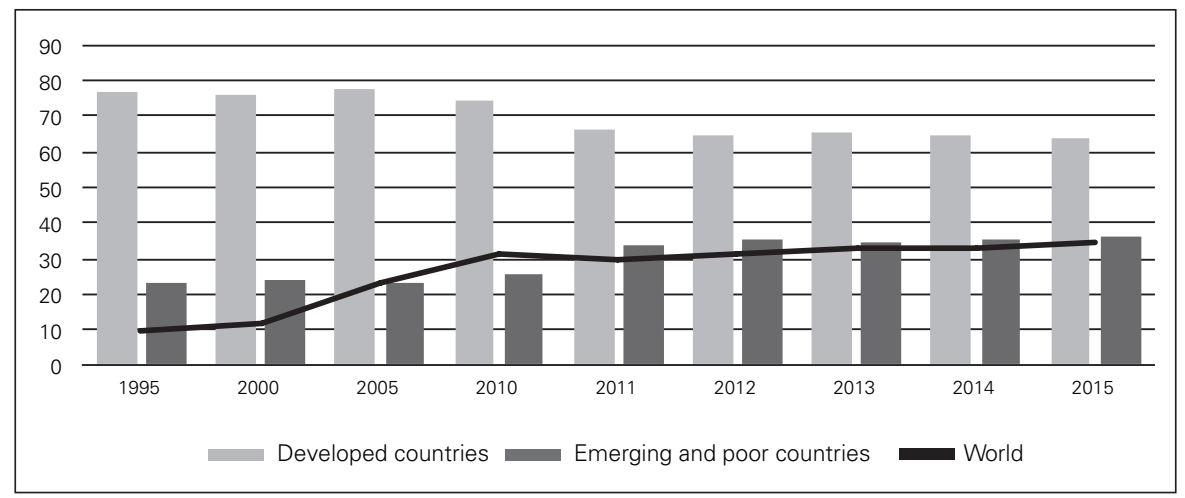

Source: Graph elaborated by the author according to data from the UNCTAD (2017). Available from: http://unctadstat.unctad.org/wds/TableViewer/tableView.aspx.

Within the dimension of productive globalization, a significant expansion of long-term international investments beyond the geographical extension of the triad countries $^{1}$ can be observed. The process of opening towards international capital devised by the formulators of economic policies in the emerging countries resulted in the attraction of bulky international investments in the 1990s. Graph 2 shows the evolution of FDI stocks within the global economy from the 1990s. These stocks grew from $9.6 \%$ of theglobal GDP in 1990 , to $24.5 \%$ in 2005 , and $34.6 \%$ in 2015. This expansion of the FDI stocks in relation to the global GDP thus merely confirms the rise in the levels of businesses' internationalization on a global scale.

Graph 2 shows that the growth of FDI at the global level also to a large extent derives from the increasing productive internationalization of the emerging economies. Even if the FDI stocks within developed economies continue to be higher than those of emerging countries, this level was substantially reduced from the 1990s. In 1990, for example, $76.7 \%$ of the FDI stocks were invested in developed countries. Throughout the decade of the 2000s, this percentage was reduced due to the surge of incoming FDI within emerging economies. In 2013 and 2014, the flows of FDI that were allocated within emerging economies even surpassed that received by developed economies.

\footnotetext{
${ }^{1}$ The triad countries is a designation used to describe the United States, Western Europe, and Japan, mainly in the Cold War period. The countries in the Triad can be found within the group of rich and developed global economies.
} 
Table 1: Liquid stocks of international assets and debts within the global economy in \% of the types of actives and in billion US\$

\begin{tabular}{|l|c|c|c|}
\hline \multicolumn{1}{|c|}{ World (in US\$ billion) } & $1980-1984$ & $1990-1994$ & $2000-2004$ \\
\hline \% of FDI & 7.124 & 26.411 & 76.142 \\
\hline \% of capital & 15.6 & 17.9 & 21.8 \\
\hline \% of debts & 4.9 & 9.5 & 15.9 \\
\hline \% of others & 75.1 & 69.4 & 58.7 \\
\hline Total & 4.4 & 3.3 & 3.6 \\
\hline
\end{tabular}

Table from Kose et al. (2009) modified by the author. The authors consider the five-year average for one of the three periods. The others are investments mainly targeted towards financial derivatives.

This period is also marked by a deepening of financial globalization. The removal of capital controls and the opening of capital accounts mainly within emerging economies resulted in a significant growth of short-term foreign investments within the global economy (Abdelal, 2007).

This phenomenon becomes evident from the data in Graph 1. Between 1980-1984 and 2000-2004, there was a near ten-doubling in relation to the growth in the international assets and debts within the global economy. In this period, the total amounts increased from the average level in the period from (1980-1984) of around US\$ 7 trillion, to a level of around US\$ 76 trillion as an annual average between 2000-2004. This increase is a result not only of the growth in the FDI stocks, but also of the expansion of international banking activities, stock market investments, public and private bonds, and financial market derivatives operations. Thus, the economic globalization of recent decades is to a large extent a reflection of the gigantic growth of transactions which do not only involve long-term investments, but mainly short-term financial assets that are traded within global financial markets. The magnitude of this process is noted in this statement by Brender and Pisani (2010, p.22):

Between the early 1970s and the Asian crisis of 1997-98, transfers of savings - measured by the world current-account imbalance - barely increased, fluctuating around $1.2 \%$ of World GDP. Over the same period, however, international financial flows rose from $1 \%$ of world GDP to more than $8 \%$.

These data, referring to the deepening of commercial, productive and financial globalization, merely confirm the perception of a growing internationalization of the global economy in the 1990s and 2000s. Yet, from the advent of the global crisis of 2008, the global economy entered a new phase marked not only by deceleration of global growth, but also by a significant reduction in the indicators for internationalization of the global economy.

In this period, the FDI flows were considerably reduced from 2008. Between 2007 and 2009, the FDI contracted by approximately $30 \%$ within a global eco- 
nomy of US\$ 1.9 trillion in 2007, to around US\$ 1.1 trillion in 2009. The global trade also registered a noticeable reduction, mainly from the last semester of 2008 and throughout 2009. Even though these rates resumed an upwards trajectory in recent years due to the incipient economic recovery, the speed and the rhythm of this process is inferior to that which was registered throughout the 2000s and until the beginning of the economic crisis of 2008.

Data from the Bank for International Settlement (2017) indicate that the international assets of the banks were reduced from $60 \%$ of global GDP in the period from 2007-2009, to approximately $40 \%$ in 2013. This contraction was even more accentuated within the Euro zone, because of the halting and reversal of the flows of international capital that were redirected towards surplus-generating emerging economies throughout the 2000s (Manzi, 2014). In this regard, the stagnation of globalization of international finances was an event which was more decisive for advanced economies within the Euro Zone, rather than constituting an essentially global phenomenon.

This scenario seems to indicate that the period of accelerated growth of economic globalization reached its endpoint as the global crisis of 2008 erupted. The stagnation of the global economy can be understood through the words of Sharma (2016, p.2):

In the 2010s, for the first time since the 1980s, global trade have growing more slowly than the global economy. Big international banks have pulled back to within their home borders, afraid to loan overseas. After surging for more than three decades, flows of capital reached a historic peak of $\$ 9$ trillion and a 16 percent share of the global economy in 2007, then declined to $\$ 1.2$ trillion or 2 percent of the global economy - the same represented in 1980.

The advent of the crisis of 2008 had immediate effects on the process of economic globalization. These data only reaffirm the perception that the second phase of globalization which had its beginning from the early 1990s reached its end with the crisis of 2008. This conjuncture should not be interpreted as the beginning of a reversal of the process of economic globalization, but should rather be understood as a sign that the phase of more accelerated growth reached its limit with the onset of the global crisis of 2008 .

\section{THE ECONOMIC GLOBALIZATION IN THE GLOBAL POST-CRISIS CONTEXT OF 2008: SYSTEMIC LIMITS AND DOMESTIC IMPASSES}

The economic globalization has entered a new phase which is marked by stagnation of the international economic flows upon the eruption of the global crisis of 2008. The motives that explain this process of relative stagnation of the rates of growth in the aggregates linked to global trade, long-term investment, and short- 
-term financial capital is a merger of a series of conjunctural dynamics, which nonetheless also to a large extent reflect global macro trends which had their beginning in the post-crisis global context from 2008. Hence, it becomes possible to distinguish dynamics at the political, economic and even ideational levels.

First, the onset of the global crisis of 2008 became a landmark within the world economy, which directly reflected upon the process of economic globalization. The extent of the economic recession can only be compared with that which occurred in the Crash of 1929, when the global economy entered the most profound recession of the $20^{\text {th }}$ century.

Its effects also had direct repercussions on the international economic flows. In the beginning of 2009 , for example, annual exports were reduced with $30 \%$ in the case of China and Germany, and with as much as $45 \%$ in the case of Singapore and Japan. These economies - with exception of China - thereby entered a profound economic recession throughout 2009. The global economy only did not undergo a more serious economic recession because of the economic performance of the emerging countries, which despite the crisis still registered a GDP growth of $2.8 \%$ in 2009 (Roubini and Mihn, 2010).

Yet, the continued downturn in international trade and investment in the 2010s suggests that the stagnation of economic globalization is not only a consequence of the global economic conjuncture. According to a IMF report (2016, p.85) on the perspectives for the global economy:

[...] the slowdown in trade growth since 2012 is to a significant extent, but not entirely, consistent with the overall weakness in economic activity. Weak global growth, particularly weak investment growth, can account for a significant part of the sluggish trade growth, both in absolute terms and relative to GDP. Empirical analysis suggests that, for the world as a whole, up to threefourths of the decline in trade growth since 2012 relative to 2003-07 can be predicted by weaker economic activity, most notably subdued investment growth. While the empirical estimate may overstate the role of output, given the feedback effects of trade policy and trade on growth, a general equilibrium framework suggests that changes in the composition of demand account for about 60 percent of the slowdown in the growth rate of nominal imports relative to GDP.

In other words, the strong reduction in the rate of expansion of international trade is, to some degree, linked to the conjuncture of the world economy in the global post-crisis of 2008. But the dynamic of the global economy is by itself insufficient to explain the more persistent process of stagnation in the expansion of international trade from the beginning of the 2010s.

Apart from the economic variable, the stagnation of the process of economic globalization is also linked to predominantly political dynamics. While some of these dynamics are located at the level of national states, others can be situated at the systemic level.

With regards to the systemic aspects, the loss of momentum of the economic 
globalization is a result of the impasses within the global governance agendas. As early as in the 1970s, Nye and Keohane (2001) perceived that as the process of economic internationalization would advance, one of the central demands within the global governance agenda would concern the intensification of international cooperation. The growth of economic interdependence generated a demand for international regimes in order to resolve the problems related to collective action and convergence of rules and patterns for state conduct, with regards to questions that involved the need for international cooperation.

The slowdown of the global governance agendas was already a visible phenomenon before the eruption of the global crisis of 2008. The impasse in the negotiations to finish the Doha Round constitutes an example of the difficulties in the construction of international consensus around the deepening of international cooperation in relation to economic issues (Narlikar, 2010). In any case, these obstacles only became more evident with the crisis of 2008, when the main developed and developing states, faced with the risks of deterioration of the global economic system, decided to pursue mechanisms for the deepening of international cooperation.

The transformation of the financial G20 in a meeting between the leaders of the largest global economies from 2008 reflects the need for cooperation and coordination, not least concerning how to manage the international financial crises. At an initial moment, the G20 successfully reached its main objective which was to diminish the imminent risks of a collapse of the entire global financial system upon the bankruptcy of the North American investment bank, Lehman Brothers. Yet, the reformist drive of the G20 to advance agendas for international cooperation and economic liberalization within the global economy lost momentum throughout the subsequent years upon the financial crisis. In the words of Mahbubani (2013, p.255) "When the crisis was over, the G-20 nations went back into their bad old habits of focusing on short-term national interests, which trumped long-term global interest". In this context, the incapacity to deepen the international cooperation might be understood through systemic variables that have made the negotiations more complex.

Firstly, there is a growth in the number of actors involved within international negotiations, which naturally results in a greater degree of difficulty in the construction of consensus within the multilateral negotiations. The first negotiation round of the GATT which took place in 1947 counted with the participation of 23 countries. In contrast, the negotiations within the Doha Round initially involved a total of 164 nations. The UN system is another example of an institution that underwent a growth in the number of actors involved throughout the decades after the second world war (Hales, Held and Young, 2013).

Apart from this, the heterogeneity among the members within the international system has also increased due to the ascent of the emerging countries. The main informal forum for international discussions until the transformation of the G20 into a meeting among heads of states was the G7. The G7 was formed in the 1970s and is a group of countries which are characterized by similarities in their political, economic and social systems, and which mainly represents the interests of market democracies or Western democracies. On the other hand, as the G20 became the main international forum for cooperation, it also came to comprise of more heterogeneous 
countries that are distinct from the G7. This heterogeneity can be observed through the existence within the G20 of political regimes and economic systems that differ highly, which naturally makes the group more complex (Kupchan, 2013).

Not by chance, Bremmer and Roubini (2011) crowned the term "G-Zero" to characterize the G20's (lacking) capacity for international consensus construction. This situation will likely produce more conflict than cooperation, which tends to reduce national governments' capacity to implement global economic liberalizing agendas. In the words of Bremmer and Roubini (2011), "The result will be intensified conflict on the international stage over vitally important issues, such as international macroeconomic coordination, financial regulatory reform, trade policy and climate change".

A second systemic factor relates to the higher degree of complexity of the agendas that are debated within multilateral forums today, as compared to earlier decades. The reduction of tariffs was a central issue in the negotiation rounds of the GATT until the creation of the WTO in the 1990s. But from the 1990s and onwards, tariff barriers have already reached a relatively low level in relation to the historical benchmark, which tends to reduce the impact of liberalization exclusively through the lowering of import tariffs. Hence, in order to reach a higher degree of liberalization of international trade, the issues that are left for discussion are naturally more complex than merely the reduction of trade tariffs and involve technical barriers to trade, intellectual property, subsidies, and environmental issues amongst others. In the words of Hale, Held and Young (2013):

Lowering tariffs might bring more job and profits to competitive producers and take them away from noncompetitive ones, even as they brought down the cost of products for consumers. The impact of the trade deal, however, was largely limited to these basic distributional questions. But once tariffs had been reduced, firms found that many other aspects of regulation such as divergent environmental and safety standards (or lack thereof), made it difficult to trade across borders. These issues are much harder to negotiate over, because the basic distributional question - who wins and who loses - has become compounded with other policy issues, some of which touch on basic social principles.

Another aspect of institutional nature which complicates the negotiation of international economic issues derives from the fragmentation of multilateral agendas. A clear example of this phenomenon is the negotiations that involve the regulation of financial and monetary issues, where no single institution is responsible for the process of rule creation, regulation, and monitoring. This situation eventually creates a complex web of accords, which in many cases revolve around the same issue, or which eventually might provide obstacles to the creation of rules for monitoring of an issue upon which agreement has been reached. In the same way, the existence of institutional fragmentation stimulates the actors to negotiate about issues in the institutions within which they wield the largest amount of influence to see their interests attended (Helleiner, 2014). 
An example of this phenomenon is the negotiations about intellectual property which take place both within the WTO, within the Global Organization for Intellectual Property (GOIP), and within the United Nations Food and Agricultural Organization (FAO). In the same context, the negotiations involving an agreement on the regulation of the financial sector have become fragmented among the IMF, the G20, and the BIS. Thus, institutional fragmentation eventually spurs countries to negotiate within the institutions that suit them, which has reduced the efficiency of the rules that have been adopted within the multilateral sphere (Hale, Held and Young, 2013).

The stagnation of the global agendas is also to a large measure a reflection of dynamics that are rooted at the national level. The repercussions of the onset of the global crisis of 2008 had some limited short-term effects on the process of insertion of the major economies within the international system. The initial responses from the national governments were more focussed on impeding the aggravation of the economic recession through the use of contra-cyclical fiscal policies, than through the adoption of ought right protectionist measures. The domestic conjuncture of some of the central actors within the economic globalization became increasingly refractory in relation to this development.

An initial factor relates to a certain degree to the exhaustion of the US hegemony within the international order. The current global order is to a large extent a result of the leadership exercised by the United States since the Bretton Woods Conference. At first, the North American leadership played an important role in assuming the transition costs of an economic international order idealized in the middle of the 1940s (Ikenberry, 2001). Even after the relative decline of the United States within the international system, the US' capacity for leadership was important in the period of acceleration of globalization from the 1990s, and even in the period of greater tension from the beginning of the global crisis of 2008 .

Yet, a decline in the willingness of the United States to exercise the function of leader within the international economic order can be noted. This dynamic within the United States to a certain extent reflects a lesser degree of readiness on behalf of domestic actors in exercising a leading role in relation to different global agendas, and not only in relation to issues regarding cooperation within international affairs. As Nye (2017, p.16) highlights:

The U.S. Senate, for example, has failed to ratify the UN Convention on the Law of the Sea, despite the fact that the country is relying on it to help protect freedom of navigation in the South China Sea against Chinese provocations. Congress failed for five years to fulfil an important U.S. commitment to support the reallocation of International Monetary Fund quotas from Europe to China, even though it would have cost almost nothing to do so. Congress has passed laws violating the international legal principle of sovereign immunity, a principle that protects not just foreign governments but also American diplomatic and military personnel abroad. And domestic resistance to putting a price on carbon emissions makes it hard for the United States to lead the fight against climate change. 
The importance of the United States' leadership within the global order cannot be underestimated. Even though the relative significance of the US economy has diminished on the global level, and the existence of international institutions and regimes guarantee a higher degree of insulation of these political processes, the United States nonetheless still occupy an important role in leading global agendas — not least regarding economic issues.

A second factor regards the resurgence of forces that can be characterized as populist and nationalist, which affects the capacity of national governments to implement economic policies that imply a higher degree of insertion of individual states within international economic flows. This context results from domestic dynamics that are marked by the reappearance of populism, mainly within the North American countries. ${ }^{2}$ Essentially, populism can be viewed as a political movement which tends to be anti-plural and critical of the political and economic elites, which eventually reduces society into two groups: "elite" and "people". Muller (2016, p.19-20) defines contemporary populism in the following manner: "Populism, I suggest, is a particular moralistic imagination of politics, a way of perceiving the political world that sets a morally pure and fully unified - but, I shall argue, ultimately fictional - people against elites who are deemed corrupt or in some other way morally inferior".

The ascent of populist forces is linked to a conjunction of political, economic, and cultural factors. In a certain way, the political system's credibility crisis within the developed economies is an older reflection of the crisis of representatively of the Western democracies, but this phenomenon reached a peak from 2008, with the deterioration of the economic situation. The fiscal crisis in these countries curtailed their governments' capacity to provide public goods and reflected negatively on the income stagnation of the middle class. The increase in economic inequality spurred the perception of the dysfunctionality of the political and economic system of the developed countries ${ }^{3}$ (Milanovic, 2016). Furthermore, questions related to cultural unity, nationalism, terrorism, and immigration, which have gained ever more attention within the political debate in these countries, should also be considered in this respect. In practise, the ascent of populist forces derives from a combination of diverse elements of political, economic, and cultural character (Diamond, 2018).

Despite the factors that explain the ascent of populist forces within the economies of the North Atlantic, the fact is that these movements contain an anti-establishment nature, which consists in questioning the political and economic status quo of the Western democracies. The economic status quo within developed eco-

\footnotetext{
${ }^{2}$ It is important to underline that populism is a term within political science which is used to analyze political phenomena mainly in Latin America, but the term has its roots in the United States of the $19^{\text {th }}$ century. About the concept of populism, see Judis (2016) and Muller (2016).

${ }^{3}$ In fact, the growing income inequality in some developed economies is a phenomenon which had its beginning from the middle of the 1980s, and which even contributed to induce economic policy errors in the United States, for example. Yet, the crisis of 2008 eventually led to the resurgence of the problem of inequality, economic recession, and the significant rise in the unemployment rates of developed economies.
} 
nomies is, to a large extent, determined by the integration of these countries within the global economy. Or rather, the populist leaders directly attack the globalizing forces for the economic problems in their countries, which tends to weaken the political forces that are committed to the adoption of policies that imply a growing internationalization of the national economy.

Not by chance, one of the central proposals of the then presidential candidate, Donald Trump, was to blame the growing economic interdependency among the United States and Mexico and China for the economic ills of the US. Contrary to what the economic establishment had professed, the deepening economic globalization allegedly did not benefit the "people", but only a globalist elite, which invariably also was deemed as corrupt. In this context, the resurgence of populist forces in 2016, with the election of Donald Trump in the United States and the UK's exit from the European Union (EU), considerably weakened the economic agendas of developed countries which were aimed towards policies that would imply a higher degree of international insertion.

Even though the populist wave has suffered a drawback with the election of Emmanuel Macron in France, and with the continuity of Angela Merkel in Germany, the strengthening of groups that are negatively minded towards economic globalization significantly reduces the domestic agendas aimed at promoting a higher degree of internationalization of the national economies. In other words, regardless of the fact that candidates with proposals that are hostile towards economic globalization have not been elected, the strengthening of such ideas implies a reduction of the margin of action of national governments in the establishment of economic policies aimed towards a higher degree of internationalization of national economies.

Finally, there is an ongoing process of ideational fragmentation with relates to the organization of the very international economic order. The acceleration of the process of globalization from the 1990s unfolded, in part, because of the existence of a relative consensus with regards to the need for a higher degree of integration with the global economy, and mainly with the emerging countries. In this period, a relative convergence around the models of international insertion of the main emerging economies can be observed: India, Mexico, Brazil, Turkey, China and Indonesia did all in varying degree adopt strategies for international insertion which resulted in a growing process of economic integration of these countries within the global economy. Even though this process has not been completely homogenous with respect to the dimensions of economic globalization, (commercial, productive, and financial) a convergence of important emerging economies with Western democracies can to some measure be observed, mainly with regards to the process of internationalization of national economies.

This trend did not ought right to succumb with the global crisis of 2008 , but the faith in the unfailing character of global markets reached a point of exhaustion with the growing perception of the risks and excesses that were committed by fir$\mathrm{ms}$ within the financial sector. On the one hand, the greater need to regulate firms within the financial sector became evident, but no consensus regarding the relation between state and market was reached, as had otherwise been the case in the post-war period which was expressed through the compromise around embedded libe- 
ralism. In this respect, contrary to what had occurred in other periods of the reorganization of the international economic order, the aftermath of the global crisis of 2008 is to a large extent marked by a greater diversity of models of capitalism within the global economy (Helleiner, 2010).

This increased degree of heterogeneity of socio-economic systems ${ }^{4}$ does not represent the existence of a dispute such as the one that took place in the 1930s - a dispute between liberal capitalism and autarkic fascism - or during the cold war - with the confrontation between liberal capitalism and Soviet communism. But this heterogeneity does reduce the capacity of states in the construction of consensus, mainly with respect to international macroeconomic coordination. Kirshner (2014, p.14-15) resumes this problem in the following:

Ideas about money and finance are much less homogeneous than they once were. And the security interests of key players at the monetary table are more varied than they have been in close to a century. In the second half of the twentieth century every major effort to reconstitute the international monetary order was undertaken by the United States and its political allies and military dependencies. This is no longer the case. For the first time in memory, the major players in the international monetary game have diverse, and often conflicting, political interests. This suggests a very bumpy ride ahead for global macroeconomic affairs.

Globalization is a phenomenon which essentially is rooted in political, economic, and even technological dynamics. The acceleration of globalization from the 1990s is not an aleatory phenomenon; it only occurred as a consequence of important transformations within the global political scenario, and it is intrinsically linked to political, economic, and even technological questions. Between the beginning of the 1990s and the eruption of the global crisis of 2008, the economic globalization has gone through a period of accelerated expansion. From 2008, the global economy entered a new economic cycle - marked mainly by a deceleration within developed countries - which reflected negatively upon the expansion of international trade, long-term investments, and even on international finance. But this deceleration in the international economic flows is not only a reflection of a new global conjuncture.

The cooling down of the process of economic globalization from 2008 is a result of the global economic conjuncture marked by a strong slowdown in growth rates and the exhaustion and incapacity of national governments to deepen the cooperation within the field of global governance. This dynamic of stagnation can be viewed through the crisis of the multilateral system of international trade, as displayed by the

\footnotetext{
${ }^{4}$ Buzan and Lawson (2014) establish a typology of four socioeconomic systems: liberal democratic capitalism (The United States, Australia), social democratic capitalism (Japan, Finland), competitive authoritarian capitalism (Malaysia, Russia), and state bureaucratic capitalism (China, Saudi Arabia). This typology should not be understood through static distinct criteria, but rather represents ideal types of economic models.
} 
incapacity of national governments to reach an agreement to conclude the Doha Round, and by the loss of momentum and capacity on behalf of the national governments to construct international consensus from the establishment of the G20 as a main forum for the promotion of international cooperation involving mainly economic issues. The possibility that the G20 could create a new "Bretton Woods", for example, did not materialize from the beginning of the 2010s (Helleiner, 2010).

This conjuncture does not necessarily indicate that the global economy is passing through a process of reversion of economic globalization, as occurred in the 1930s. Despite the impasses observed within international negotiations, there has nonetheless been a certain degree of misperception and exaggeration of the shortcomings of global governance from the crisis of 2008. The present impasses within global economic governance cannot be understood as a retrocession or even as a dismantling of the structures of global governance. As Drezner (2014, p.57) observes, "Whether one examines the outcomes, outputs, or operations of international institutions, the system worked - not perfectly, but good "enough".

In any case, the indicators that measure the phenomenon of economic globalization demonstrate that from 2008, the economic globalization entered a new phase marked by the cooling down and stagnation of the process of internationalization of national economies. It is still too early to determine, but the surge of populist forces within the domestic sphere and mainly within the developed economies could mark a new phase of economic globalization, possibly even characterized by a reversion of the internationalization of national economies. This is because, for the first time since the 1940s, the main countries that contribute to spur the economic globalization on a global scale have undergone significant changes within their domestic environment, as political forces opposed to the internationalization of these economies have gained space. Apart from that, the existence of structural dynamics, which even had become evident before the global crisis of 2008 - such as multipolarity and heterogeneity within the international system, complexity, and fragmentation of the global agendas and crisis of the very ideational consensus of global capitalism - further reduce national governments' capacity to implement measures that propel the phenomenon of economic globalization. In this regard, contrary to what occurred in the decades of the 1990s and 2000s, the slowdown of economic globalization at an initial moment after the crisis of 2008 could inaugurate a new phase which will be marked by the stagnation and even the reversion of the phenomenon of economic globalization on a global scale.

\section{REFERENCES}

BANK FOR INTERNATIONAL SETTLEMENTS. (2017), 87 th Annual Report. Basel: Bank for International Settlements.

BREMMER, Ian; ROUBINI, Nouriel. (2011), “A G-Zero World. The new economic club will produce conflict, not cooperation". Foreign Affairs, March/April issue.

BRENDER, Anton; Pisani, Florence. (2010). Global Imbalances and the Collapse of Globalised Finance. Brussels: Centre for European Policy Studies.

BUZAN, Barry; LAWSON, George. (2014) "Capitalism and the emergent world order". International Affairs 90: I, 71-91. 
DIAMOND, Larry. (2018) “The liberal democratic order in crisis”. The American Interest. Disponível em: https://www.the-american-interest.com/2018/02/16/liberal-democratic-order-crisis/ Access: 25 February 2018.

DREZNER, Daniel W. (2014) The System Worked. How the World Stopped another Great Depression. Oxford: Oxford University Press.

FRIEDEN, Jeffry A. (2006) Capitalismo Global. História Econômica e Política do Século XX. Rio de Janeiro: Jorge Zahar Editor.

G20. 2009 (2017). The Leaders' Statement, The Pittsburgh Summit. Available at: https://www.g20.org/ sites/default/files/g20_resources/library/Pittsburgh_Declaration_0.pdf Access: 15July2017.

HALE, Thomas; HELD, David; YOUNG, Kevin. (2013), Gridlock. Why Global Cooperation is Failing When We Need it Most. Cambridge: Polity Press.

HELD, David et al. (1999) Global Transformations. Politics, Economics and Culture. Stanford: Stanford University Press.

HELD, David; MCGREW, Anthony (2001) Prós e Contras da Globalização. Rio de Janeiro: Jorge Zahar Editor.

HELLEINER, Eric. (2014), The Status Quo Crisis. Global Finance Governance after the 2008 Meltdown. Oxford: Oxford University Press.

HELLEINER, Eric. (2010) "A Bretton Woods moment? The 2007-2008 crisis and the future of global finance". International Affairs, 86: 3, pp. 619-636.

HELLEINER, Eric. (1994) States and the Reemergence of Global Finance. From Bretton Woods To The 1990s. Cornell: Cornell University Press.

HOBSBAWN, Eric. (1995) Era dos Extremos: O Breve Século XX. São Paulo: Companhia das Letras.

JUDIS, John B. (2016) The populism explosion: How The Great Recession Transformed American and European Politics. New York: Columbia Global Reports.

KEOHANE, Robert O. (1984) After Hegemony. Cooperation and Discord in the World Political Economy. Princeton: Princeton University Press.

KEOHANE, Robert O.; NYE, Joseph S. (2001) Power and Interdependence. New York: Longman.

KUPCHAN, Charles A.(2012)No one's world.The West, The Rising Rest And The Coming Global Turn. New York: Oxford University Press.

MANZI, Rafael H. D. (2014) "Os critérios de convergência de Maastricht e as instabilidades macroeconômicas na formação da crise econômica e financeira nos GIPS”. Carta Internacional, Vol. 9, n. 2, pp. 49-71.

MILANOVIC, Branko (2016) Global Inequality. A New Approach for the Age of Globalization. Cambridge: Harvard University Press.

MULLER, Jan-Werner. (2016) What is populism? Philadelphia: University of Pennsylvania Press.

NARLIKAR, Amrita. (2010) "New powers in the club: the challenges of global trade governance". International Affairs, $86: 3$, pp. 717-728.

NYE, Joseph S. (2017) “Will the liberal order survive?” Foreign Affairs, January/February Issue.

NYE, Joseph S. (2010) The Future of Power. Washington: Public Affairs.

ROUBINI, Nouriel; MIHM, Stephen. (2010) A Economia das Crises. Um Curso-relâmpago sobre o Futuro do Sistema Financeiro Internacional. Rio de Janeiro: Editora Intrínseca.

RUGGIE, John G. (1982), "International regimes, transactions, and change: Embedded liberalism in the post economic order”. International Organization, Volume 36, Issue 2, International Regimes, pp. $379-415$.

SHARMA, Ruchir. (2016) The Rise and Fall of Nations. Forces of Change in the Post-Crisis World. New York: W. W. Norton \& Company Ltd.

STURGEON, Timothy et al. (2013) "O Brasil nas cadeias globais de valor: implicações para a política industrial e de comércio”. Revista Brasileira de Comércio Exterior. Rio de Janeiro: RBCE, N 115, April-June, pp. 26-27.

WORLD TRADE ORGANIZATION. (2011) World Trade Report. The WTO and preferential trade agreements. Geneva: WTO. 